\title{
Editorial
}

\section{Faça o que eu digo, mas jamais faça o que eu faço}

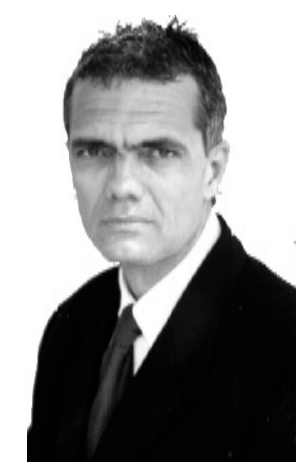

Marco Antonio Guimarães da Silva,Med.Dr.Sci. marco@atlanticaedu.com.br

A prematura morte por CA de pulmão de Carlos Azeredo, um dos precursores da fisioterapia respiratória no Brasil, me remeteu aos tempos de juventude, no final dos anos 70 , época em que passávamos, Azeredo e eu, algumas horas semanais despreocupados e conversando sobre amenidades.

Nunca deixou de me surpreender a quantidade de cigarros que Azeredo à época já consumia: algo em torno de 4 a cinco maços diários. Lamentavelmente, o quadro que acabei gravando, após esses quase 36 anos de convivência com o Azeredo, foi o do sofrimento de um paciente terminal com câncer, lúcido até praticamente a hora em que morreu. Ainda inconformado com o sentimento de perda do amigo, perguntava-me: por que diabos, logo ele que conhecia profundamente os temas relacionados a CTI e pulmão, não se dera conta do lento suicídio a que se submetera ao longo desses anos?

Derivando para outra área, lembrei-me também, que alguns poucos trabalhos publicados em periódicos apontam para uma alta prevalência de problemas na coluna vertebral e algias vertebrais em pessoal da área de saúde, especialmente os fisioterapeutas.

Algumas ordens e ou sugestões que levamos até nossos pacientes, adaptadas às circunstâncias de cada patologia, podem incluir restrições a exposição a fatores carcinogênicos, cuidados para preservação do sistema músculo-esquelético, proteção do aparelho cardiovascular etc. Pedimos a esses pacientes que assumam a responsabilidade pelo cuidado de si mesmos, em função de uma biomecânica e higiene corporal correta e somos incapazes de nos proteger sob a mesma ótica.

Porque fazemos exatamente o oposto do que indicamos aos nossos pacientes?

Um das dificuldades que enfrentamos para equacionar a questão está na pouca realização de pesquisas com trabalhos na área preventiva, o que obviamente nos leva a ter uma produção de artigos científicos muito aquém do que necessitamos. Em editorial passado optei por justificar e analisar, a luz do pensamento Wittgensteiniano, a preferência do ato curativo pelo preventivo na fisioterapia e a pouca produção na área.

Mas, será que somente o aumento de uma produção amparada por trabalhos científicos publicados em periódicos poderia re-dimensionar o problema e nos levar a re-pensar a forma como agimos? Ou a fonte de tamanho paradoxo estaria em um pensar que transcende a simples explicação de falta de produção acadêmica?

Imagino que os estudiosos do comportamento humano já se debruçaram sob o tema e têm lá alguma teoria que justifique as nossas nocivas e imprudentes ações. Por minha parte, prefiro recorrer a uma linha de pensamento que aponte para duas direções: a primeira amparada em uma hipótese da hipocrisia inconsciente, retratada, mantidas as devidas proporções, por Montaigne (Montaigne, 1533-1592), que nos mostra uma pintura perspicaz da natureza humana e traça uma perfeita radiografia do espírito do século XVI, atenta a todas as inquietudes da época, mas que pode perfeitamente ser utilizada na atualidade:

"Para que servem esses píncaros elevados da filosofia, em cima dos quais nenhum ser humano se pode colocar, e essas regras que excedem a nossa prática e as nossas forças? Vejo freqüentes vezes proporem-nos modelos de vida que nem quem os propõe nem os seus auditores têm alguma esperança de seguir ou, o que é pior, desejo de o fazer" (Ensaios - Da Vaidade).

Há um prazer quase que visceral, quando reprimimos uma pessoa que está errada e quando, par e passo, demonstramos ter sólido domínio sobre as falhas que ora apontamos, mas longe dali, cometemos os mesmos ou piores erros do que aqueles que tentamos corrigir. Ou seja: faça o que eu digo, mas (jamais) (grifo meu) faça o que eu faço.

A segunda linha do meu pensar vai em direção ao suicídio inconsciente e aí deixo de lado o amparo psicanalítico que poderia ter de um Freud (1856-1939) ou o substrato sóciofilosófico de um Durkheim (1858-1917). Recorro a literatura de Giovanni Papini (1881-1956), na verdade a fragmentos de sua obra Relatório sobre os homens, que nos dá uma idéia muitíssimo clara da intimidade humana. Ainda que o contexto da obra de Papini se volte para o narcisismo, recolho dali uma frase que poderia ser o ponto de partida para uma reflexão mais profunda para o tema - O homem ama-se e desama-se. Não me atreverei, com receio de que possa estar cometendo uma heresia psiquiátrica, a nos classificar e relacionar como narcísicos, potencialmente suicidas, vítimas de uma sociedade niilista. Tire você mesmo as suas conclusões.

Seja como for, a desagradável sensação de que posso morrer com muito sofrimento (materializada quando da morte do Azeredo), foi para um passado remoto que não quero mais lembrar e para um futuro longínquo que não consigo imaginar. Não mais faz parte de meu cotidiano. Continuarei a pedir aos meus pacientes que se cuidem, continuarei a executar pesquisas sobre prevenção, continuarei, também, a publicar artigos sobre o tema. Mas se você, caro leitor, se deparar com um dessas publicações ou pesquisas, dou a seguinte sugestão: não tente saber se faço aquilo que sugiro que se faça e que provei que funciona. Você poderia se decepcionar! 